\title{
Ecosystems and urbanization: A colossal meeting of giant complexities
}

\author{
This article belongs to Ambio's 50th Anniversary Collection. Theme: Urbanization
}

\author{
Henrik Ernstson
}

Published online: 12 March 2021

Our Ambio article on urban transitions 10 years ago (Ernstson et al. 2010) provided a platform for our interdisciplinary team to articulate how our research from three cities could be brought together to articulate how cities and urbanization draws upon and are embedded in the dynamics of local to regional ecosystems. We wanted in essence to understand how the contested process of urbanization, a socially and economically vibrant process, is embedded within, while shaping and being shaped by equally dynamic and complex ecosystem processes near and far. How to make sense of this colossal meeting of giant complexities? Our intention was to formulate an answer to this question that was applicable across scales, from local to planetary, and across social and ecological spheres of life.

This in turn lead to our more specific argument that the then still nascent, but now mainstreamed resilience framework had to be expanded to handle what we referred to as "human-dominated ecosystems." As a body of thought, social-ecological systems theory and what Carl Folke in 2006 named "resilience thinking," had depended heavily on paradigmatic case studies from rural and conservation areas. This ranged from Buzz Holling's (1978) studies of spruce budworm dynamics, Scheffer's (1997) shallow lakes, and Walker et al. (1981) savannah studies in Zimbabwe, to "adaptive co-management"-studies, including for instance communal relations around crayfish in Sweden (Olsson and Folke 2001) and livelihood farming practices in Tanzania (Tengö and Hammer 2003). These smaller-scale rural studies, indebted to conservation ecology, were constrained in taking on "the urban" since they had not engaged with the complexity and economic and socio-material intensity of cities and urbanization, its conflicts, technologies and intersections of money and power. To organise a study through identifying ecological "regime shifts" or "social-ecological feedbacks," was difficult in urban areas if they even made sense, and the scale of urbanization was more expansive. What we were aiming to do, with Thomas Elmqvist and myself gathering the other co-authors at the first Resilience Conference in 2008 in Stockholm, before I had even defended my $\mathrm{PhD}$ thesis, was to update, extend and challenge the resilience framework to deal with the problem of thinking about cities, urbanization and ecosystems together and across multiple scales. Our effort developed resilience theory, providing a language for grasping this meeting of colossal complexities, and was at the time an important contribution to environmental science and urban ecology.

Looking back and reading the article again, I am struck with how resolutely we tested the principles of non-equilibrium ecology and how this developed lines of thought that have become part of debates in urban ecology. Here, in this brief reflection, I will focus on how we were particularly early out in using the notion of infrastructure to describe how cities-and indeed, networks of cities-appropriate ecosystems from afar and how these "technical networks" are profoundly shaped by social networks.

But what I also recognized in reading the article again, was how two key urban aspects were omitted or only vaguely articulated in the article: knowledge politics and uneven social power relations. In 2010, the same year that the Ambio article was published, I moved permanently with my family to Cape Town and I lived and researched there for almost a decade. The experience of making sense of urban environmental relations through a postcolonial and post-apartheid city like Cape Town profoundly changed my outlook and radicalized what I think environmental science should be foregrounding in seeking more viable and just conditions for life. While the dynamics of urbanized ecosystems and their interaction with social processes 
are crucial in supporting human and nonhuman life, something that my urban ecology group in Stockholm from 2003 to 2008 had emphasized, what became increasingly important to me in Cape Town was to find frameworks to make sense of how the legacies and patterning of racial, class- and gender-based relationships of power influence ecosystem dynamics and access to environmental resources. What the years in Cape Town, with further empirical studies with co-workers in Kampala, Luanda and New Orleans, got me to realise was that social-ecological systems theory, or "resilience theory," lacked a deeper and sustained engagement with theories on knowledge and power, which hampered its ability to explain situated politics of environmental knowledge (Mol 1999; Howitt and Suchet-Pearson 2003; Whatmore 2009) and wider patterns of uneven exploitation of ecosystems and people (Harvey 1996; Swyngedouw 1996; Moore 2015). While this urge to include critical theory on knowledge and power was visible already in my $\mathrm{PhD}$ thesis from 2008, it became clear to me that when "resilience thinking" was polished into a subdiscipline, it was also partially closing in on itself and becoming self-referential. It did not, I found, engage sufficiently with how scholars and environmental activists from various fields, from feminist, postcolonial, Scienceand-Technology studies and Marxist perspectives had shown how power, capital, conflicts and uneven development had to be addressed as underlying causes of unsustainable use of ecosystems. There was rather a tendency of finding a "managerial fix" to problems, without addressing root causes, a critique that has pursued resilience theory since its beginning (Nadasdy 2007; Kaika 2017). While others have since sensitized the resilience discourse to some of these critical aspects (see e.g., Welsh 2014; Ingalls and Stedman 2016; Ernstson and Sörlin 2019, pp. 8-21; Smirnova et al. 2020), I found it better to more clearly break with systems theory writ-large and understand urban ecology as inherently situated within economic, social, cultural and political relations of power and conflict (e.g., Ernstson and Sörlin 2019; Ernstson and Swyngedouw 2019). This has proved incredibly enriching and rewarding and I will provide some examples of this direction for urban ecology at the end of this short reflection. Before that though, let's turn to our Ambio article and what it contributed on its own.

At the outset of the article we make clear that when you take on "the urban," you need to account for the sheer scale of urbanization as a socio-ecological phenomenon. Cities are, from Harvey's (1996) political economy perspective, social and material articulations of much wider historical and geographical, and thus environmental processes of capital accumulation. In urban studies this is known as the principle of agglomeration: social interactions, power relations and economic transactions are concentrated and intensified through that space or thing we call "the city;" it is not the market square that gathers the city, but the city creates the conditions through which the market emerges and through which capital and uneven wealth accumulation can occur (Cronon 1991). The origins of the "stuff" required to literally build the city, feed the increasing unequal consumption and metabolization of water, food, energy, transport, leisure and the likes are, in crucial aspects, "pulled in" from afar. The city and the process of urbanization, through the law of agglomeration and elite concentration, tends to dominate and define rural hinterlands, thus interlinking a set of places and ecosystems so that energy and materials can be mobilized for the consumption and production patterns of cities and urban populations (Cronon 1991; Swyngedouw 1996). This process has furthermore, as we head deeper into the $21 \mathrm{st}$ century, clearly been elevated to a planetary scale as hypothesized by Henri Lefebvre more than fifty years ago (Lefebvre 2003 [1970]; Brenner and Schmid 2014; Sidaway et al. 2014).

Within this wider context, our Ambio article was set up to shift the debate of how to account for and think about urban ecosystems. For us, urban ecology could not simply be conceived as something biophysical, but it was also social and cultural. It could also not simply be viewed from within the city proper itself. Urban ecology had to be construed as interacting across scales, from within the city to the vast lands and ecosystems on which the city proper drew to energise and animate itself. This is also how the first two of our four-point argument to "broaden the theoretical discussion regarding urban resilience" were formulated.

We wanted firstly to use our experiences of studying Cape Town, Phoenix and New Orleans, to show how "cross-scale interactions" are key in altering ecosystems that in turn support urban systems with water, food, materials and energy, pushing them potentially "across thresholds" undermining livelihoods, economies and, broadly phrased, sustainability. Perhaps more stringently than anybody had done before for urban systems, we applied Thom and Zeeman's mathematical and highly stylized model of how "slow variables" and disturbances can produce far-reaching "regime shifts" that undermines the socio-ecological viability of a city. This departure point from mathematics was quite common in early articles on resilience and non-equilibrium ecology, but can certainly be accused of over simplifying something complex and highly contested. Ten years after, I can still sense the fascination and early kinship I felt with this stylized mathematical entry point. I had done my undergraduate studies in physics and applied mathematics and in shifting to ecology, it was intriguing to find a bold "grand theory" that sought to explain the dynamics and stability of complex 
ecosystems by departing from mathematicians I had studied before. The likes of Poincaré and Lyapunov were used to describe the depth, width and nonlinear thresholds of ecological stability domains, which was first developed succinctly by Lewontin (1969), later followed by Holling (1973). Based on this abstract theoretical departure point and with observations from our three case study cities, our Ambio article argued that urban governance had to focus on identifying the slow variables and potential thresholds that governed how cities were dependent on local to regional ecosystems.

The second part of the argument was to draw on economic geography's development of "systems of cities" and reconceptualize cross-scale interactions as "interdependencies between technical and social networks that tie cities together and sustain flows of energy, matter, and information" (Ernstson et al. 2010, p. 532). Cross-scale interactions, a difficult and quite slippery notion, had at this point in environmental science been viewed as either biophysical or social, often as "local ecological knowledge," or traced through Ellinor Ostrom's (1990) common property theory in how land was owned and used. We instead argued that a neglected but effective entry point to understand cross-scale interactions in cities and humandominated ecosystems was through "technical networks," or infrastructure networks of various kinds. This built upon and expanded the debate in urban ecology (e.g., Alberti 2008) to account for how human-made infrastructure (and trade networks) enrolled resources and biophysical processes from a vast network of distinct ecosystems. We were certainly not the first to insist on this interaction between the city proper and its hinterlands. Indeed this has been part of urban theory since its inception (von Thünen 1966 [1826]) up to the present (Arboleda 2020), and in ecology the idea was developed into cybernetic linear models already in the 1960s by Abel Wolman, Howard Odum and Paul Duvigneau (see Sukopp 2002; Ernstson and Sörlin 2019). However, in our Ambio article, and partly guided by the openness of resilience thinking to take in the world as dynamic and everchanging, our focus on technical networks tried to provide a more spatialized and non-linear framework of the metabolic interaction between the city-or more correctly, the process of urbanization-and vast hinterlands of ecosystems.

It is this second part on infrastructure that I today feel is the most interesting legacy of our Ambio article. Both in how it contributed an early albeit unacknowledged ecosystem-perspective to the "infrastructural turn" in critical geography and urban studies (Graham 2010; Carse 2012), but also because infrastructure might be the aspect least drawn upon by environmental scientists that have cited the article. The infrastructure argument was developed and fitted into the paper across a set of emails and early drafts that I exchanged primarily with Sander van der Leeuw, who shared from his deep interdisciplinary experience as an archaeologist and environmental historian. We conceptualized this infrastructural relation as socio-ecological. But we also clarified that "social networks are different from ecological networks" in that the latter are conditioned by energy and genetic transfers, whereas the former "are self-constructed by society in a process of 'alignment' or 'co-ordination." "We used this to argue that:

[It is] the sharing of information that creates the channels through which energy and matter flow. Through recursive alignment and communication processes, material and energetic resources are identified by urban stakeholders in distant local places and ecosystems, channelled into society and transformed by human knowledge and labor in such a way that they are suitable for use, and again transformed during use into forms with higher entropy, which are then disposed of.

This emphasized that we cannot study cities as islands or closed "systems" and also that the impact of urbanization is felt far afield from where the city is located. And further that the interaction between technical and social networks are not simply located in a particular "city," but rather distributed across a much wider scale of actors that are part of and influence many other cities in shaping policy, access to capital, and configuration of infrastructures. Cities are, as we wrote "loci in multiple socio-ecological and technical networks" and the enrolment of material and energetic resources hinges on social relations. This we suggested is significant in the study of urban and humandominated systems because the mediation between society and ecosystems always scales outwards on one hand, and inwards to intensify struggles over how to use urban land and how to define and build technical networks. Infrastructure then, could be used as empirical and conceptual entry points to understand cross-scale interactions and possibly the identification of non-linear ecological regime shifts, both locally and in distant places.

A first critique can be raised here. Our model was overly abstract and would probably not have passed the "simplification syndrome" test that I devised with Sverker Sörlin as a measure of how easily a model decontextualizes and de-historicizes the place it tries to explain (Ernstson and Sörlin 2019, p. 21). In trying to contribute a general theory, our analysis of the actual places of Cape Town, Phoenix and New Orleans suffered in precision.

A second critique that could be raised, from ecologists, geographers and what is today referred to as post-humanists, is that our conceptualization somewhat discounted the "agency" or "dynamics" of ecosystems. We placed too much agency on "the social," which risks downplaying the 
vibrancy and uncertainty of ecosystems in "acting back" on human-imposed uses of ecosystems. Following anthropologists and geographers, I have later with Joshua Lewis tried to address this shortcoming through a lens that views "ecosystems as infrastructure" (Lewis and Ernstson 2019). In a study that traces the 150-year infrastructural history of New Orleans, we showed how port capitalist interests linearized and simplified the Louisiana coastal landscape to increase profits from shipping, which in turn produced an unintentional ecological regime shift that was furthermore shaped by class-based and racialized politics. This study extended the Ambio article and provided a more nuanced ecological historical method to account for the dialectical dance between biophysical and infrastructuralcum-social dynamics; the abstract notions of slow variables and ecosystem thresholds became grounded in class- and race-based analyses interpreted from historical archives, environmental measurements, and the knowledge created from situated and place-based social struggles.

A more immediate problem of our Ambio article was how we went on to use the insight of "technical networks" in the third and fourth part of the argument. Instead of drawing on critical social theory that could unpack how social networks are shot through by unequal power relations, we developed a set of apolitical ideas of cities as "extreme innovation hubs" that can be "harness[ed]... to make urban governance more sensitive to ecosystem dynamics." While this observation is not unimportant, the problem lies in how a generic notion of "innovation" stands in the way, or "off-stages" a more conflictual and contested view of innovation. Our article lacked nuance and precision on innovation and rather disappointinglywhen reading it now-played into the entrepreneurial spirit of neoliberal policy making. We thus downplayed, as was common in resilience thinking, the deep-seated conflicts about land, knowledge, and decision-making that each of our case study cities actually displayed.

Knowledge politics and uneven power relations have since, but also before, figured centrally in my work with colleagues and students. More generally I have come to draw upon urban environmental history, political ecology and postcolonial urbanism (Swyngedouw 1996; Melosi 2010; Parnell and Oldfield 2014). The aim has been, and here paraphrasing urban scholar Ananya Roy (2016, p. 207), to develop a study of urbanization and ecosystem change that is "attentive to historical difference as a fundamental and constitutive force in the making of global urbanization." This has for me and collaborators meant to much more carefully question the validity of abstract frameworks, such as social-ecological systems theory and resilience theory that are, so to speak, inserted from the outside to explain a particular place. Rather I have tried to understand and theorize cities, urbanization, and ecosystems from the places we study and drawing on situated ways of knowing to understand how ecology and social justice come together (e.g., Lawhon et al. 2014, 2018; Von Heland and Ernstson 2018; Lewis and Ernstson 2019; Ernstson and Swyngedouw 2019). This does not mean to step away from developing more general theoretical frameworks for analysis and struggle (as feminists and postcolonial scholars have long showed, see Rich 1986; Roy 2016). But it means to be aware of how theory travels and the specific intellectual histories and ideological projects that theories come attached with (see Ernstson and Sörlin 2019). In a highly unequal world the attention to situated knowledges and comparative thought helps to foreground the long environmental legacies of colonialization, class- and gender-based forms of exploitation, and how scientific ways of knowing have their own biases not easily separated from social and political processes (Ernstson and Sörlin 2019). To move from "systems thinking" to situated ecologies, as I have done, does not make environmental science and interdisciplinary collaboration less important, but requires a commitment to relate scientific ways of knowing to place-based struggles and politics.

When writing the Ambio article, I was in transition; professionally I went from $\mathrm{PhD}$ studies to winning my first research grants and become a supervisor myself; geographically in moving to Cape Town; and intellectually in finding a more critical platform from where urban ecosystems and environmental change could be understood as an inherently contested process, deeply entwined in historical and geographical relations of racialized and class-based processes of capital accumulation. In this process, the Ambio article was important to me in that I got the chance to learn from my more experienced co-authors, from Sander van der Leeuw, Chuck Redman, Douglas Meffert, George Davis, Christine Alfsen, and Thomas Elmqvist, who I am sure would make different and equally important reflections on the article's importance for environmental science. What I hope to have contributed to in this short piece is to inspire and support the many efforts already existing among us urban ecologists and environmental scientists to develop interdisciplinary collaborations that explicitly consider how knowledge, power, and capital shape the "colossal meeting of giant complexities," how urbanization and complex ecosystems meet and evolve.

Acknowledgements Thanks to Bo Söderström, Zahra Kalantari and Erik Andersson, the Ambio editorial team, for the invitation to write this reflection.

\section{REFERENCES}

Alberti, M. 2008. Advances in urban ecology. Berlin: Springer. Arboleda, M. 2020. Planetary mine: Territories of extraction under late capitalism. New York: Verso. 
Brenner, N., and C. Schmid. 2014. Planetary urbanization. In Implosions/explosions: Toward a study of planetary urbanization, ed. Neil Brenner, 160-163. Berlin: Jovis.

Carse, A. 2012. Nature as infrastructure: Making and managing the Panama Canal watershed. Social Studies of Science 42: 539-563. https://doi.org/10.1177/0306312712440166.

Cronon, W. 1991. Nature's metropolis: Chicago and the Great West. New York: Norton.

Ernstson, H, and S. Sörlin, eds. 2019. Grounding urban natures: Histories and futures of urban ecologies. Cambridge: MIT Press. https://direct.mit.edu/books/book/4522/Grounding-UrbanNaturesHistories-and-Futures-of.

Ernstson, H., and E. Swyngedouw (eds.). 2019. Urban political ecology in the anthropo-obscene: Interruptions and possibilities. Abingdon: Routledge.

Ernstson, H., S.E. van der Leeuw, C.L. Redman, D.J. Meffert, G. Davis, C. Alfsen, and T. Elmqvist. 2010. Urban transitions: On urban resilience and human-dominated ecosystems. Ambio 39: 531-545. https://doi.org/10.1007/s13280-010-0081-9.

Graham, S. 2010. Disrupted cities: When infrastructure fails. New York: Routledge.

Harvey, D. 1996. Justice, nature and the geography of difference. Oxford: Blackwell.

Holling, C.S. 1973. Resilience and stability of ecological systems. Annual Review of Ecology and Systematics 4: 1-23.

Holling, C.S. 1978. The spruce-budworm/forest-management problem. In Adaptive environmental assessment and management, ed. C.S. Holling, 143-182. New York: Wiley.

Howitt, R., and S. Suchet-Pearson. 2003. Ontological pluralism in contested cultural landscapes. In Handbook of cultural geography, ed. K. Anderson, M. Domosh, S. Pile, and N. Thrift, 557-569. London: Sage.

Ingalls, M.L., and R.C. Stedman. 2016. The power problematic: Exploring the uncertain terrains of political ecology and the resilience framework. Ecology and Society 21: 6.

Kaika, M. 2017. "Don't call me resilient again!': The New Urban Agenda as immunology ... or ... what happens when communities refuse to be vaccinated with 'smart cities' and indicators. Environment and Urbanization 29: 89-102. https://doi.org/10. $1177 / 0956247816684763$.

Lawhon, M., H. Ernstson, and J.D. Silver. 2014. Provincializing urban political ecology: Towards a situated UPE through African urbanism. Antipode 46: 497-516. https://doi.org/10.1111/anti. 12051.

Lawhon, M., D. Nilsson, J. Silver, H. Ernstson, and S. Lwasa. 2018. Thinking through heterogeneous infrastructure configurations. Urban Studies 55: 720-732. https://doi.org/10.1177/ 0042098017720149.

Lefebvre, H. 2003 (1970). The urban revolution. Minneapolis, MN: University of Minnesota Press.

Lewis, J.A., and H. Ernstson. 2019. Contesting the coast: Ecosystems as infrastructure in the Mississippi River Delta. Progress in Planning 129: 1-30. https://doi.org/10.1016/j.progress.2017.10. 003.

Lewontin, R.C. 1969. The meaning of stability. Brookhaven Symposia in Biology 22: 13-24.

Melosi, M.V. 2010. Humans, cities, and nature: How do cities fit in the material world? Journal of Urban History 36: 3-21. https:// doi.org/10.1177/0096144209349876.

Mol, A. 1999. Ontological politics. A word and some questions. In Actor network theory and after, ed. J. Law and J. Hassard, 74-89. Oxford: Blackwell Publishing.

Moore, J.W. 2015. Capitalism in the web of life: Ecology and the accumulation of capital. London: Verso.
Nadasdy, P. 2007. Adaptive co-management and the gospel of resilience. In Adaptive co-management: Collaboration, learning and multi-level governance, ed. D. Armitage, F. Berkes, and N. Doubleday, 208-227. Vancouver: UBC Press.

Olsson, P., and C. Folke. 2001. Local ecological knowledge and institutional dynamics for ecosystem management: A study of Lake Racken watershed. Sweden. Ecosystems 4: 85-104.

Ostrom, E. 1990. Governing the commons: The evolution of institutions for collective action. Cambridge: Cambridge University Press.

Parnell, S., and S. Oldfield (eds.). 2014. The Routledge handbook on cities of the global south. London: Routledge.

Rich, A. 1986. Notes toward a politics of location. In Blood, bread, and poetry: Selected prose 1979-1985, ed. A. Rich, 210-232. New York: Routledge.

Roy, A. 2016. Who's afraid of postcolonial theory? International Journal of Urban and Regional Research 40: 200-209. https:// doi.org/10.1111/1468-2427.12274.

Scheffer, M. 1997. The ecology of shallow lakes. London: Chapman and Hall.

Sidaway, J.D., C.Y. Woon, and J.M. Jacobs. 2014. Planetary postcolonialism. Singapore Journal of Tropical Geography 35: 4-21.

Smirnova, V., J.L. Lawrence, and J. Bohland. 2020. The critical turn of resilience: Mapping thematic communities and modes of critical scholarship. The Geographical Journal. https://doi.org/ 10.1111/geoj.12370.

Sukopp, H. 2002. On the early history of urban ecology in Europe. Preslia Praha 74: 373-393. https://doi.org/10.1007/978-0-38773412-5_6.

Swyngedouw, E. 1996. The city as a hybrid: On nature, society and cyborg urbanization. Capitalism Nature Socialism. https://doi. org/10.1080/10455759609358679.

Tengö, M., and M. Hammer. 2003. Management practices for building adaptive capacity: A case from northern Tanzania. In Navigating social-ecological systems. Building resilience for complexity and change, ed. F. Berkes, J. Colding, and C. Folke. Cambridge, UK: Cambridge University Press.

Von Heland, J., and H. Ernstson. 2018. One Table Two Elephants. Copenhagen: 84 minutes, cinematic ethnography, Color, HD, Dolby 5:1, World Premiere In Competition at CPH:DOX 2018 20th March 2018. http://bit.ly/1T2Ethefilm.

Von Thünen, J.H. 1966 [1826]. Isolated state. London: Pergamon Press.

Walker, B., D. Ludwig, C.S. Holling, and R.M. Peterman. 1981. Stability of semi-arid savanna grazing systems. Journal of Ecology 69: 473-498.

Welsh, M. 2014. Resilience and responsibility: Governing uncertainty in a complex world. The Geographical Journal 180: 15-26. https://doi.org/10.1111/geoj.12012.

Whatmore, S.J. 2009. Mapping knowledge controversies: Science, democracy and the redistribution of expertise. Progress in Human Geography 33: 1-12.

Publisher's Note Springer Nature remains neutral with regard to jurisdictional claims in published maps and institutional affiliations.

\section{Henrik Ernstson ( $\square)$}

Address: Department of Sustainable Development, Environmental Science and Engineering, KTH Royal Institute of Technology, Teknikringen 10B, 10044 Stockholm, Sweden.

Address: Department of Geography, The University of Manchester, Manchester, UK.

e-mail: ernstson@kth.se 